\title{
Meningen med Informationskompetens
}

\author{
Af Christer Eld
}

\section{Inledning}

Begreppet informationskompetens har under det senaste decenniet fått ett allt större utrymme i svenska bibliotekssammanhang, inte minst inom högskolebiblioteksvärlden. Hänvisningar till informationskompetens är kanske mest frekvent förekommande i samband med att användarundervisning diskuteras och marknadsförs men förekommer även i mer övergripande deklarationer och dokument om bibliotekens mål och policy.

Det här är säkert inte unikt för svenska förhållanden. Det är måhända inte heller det faktum att begreppets ökade popularitet även kan relateras till ett växande intresse från bibliotekens sida att profilera sig och få större uppmärksamhet, något som gör det intressant att försöka ta reda på vilka betydelser och vilka anspråk som knyts till begreppet i den svenska biblioteksdiskursen.

I föreliggande artikel, som bygger på en magisteruppsats framlagd vid Uppsala universitet, Institutionen för ABM, estetik och kulturstudier, (Eld, 2001) hop- pas jag kunna belysa och beskriva meningen med begreppet informationskompetens i ett biblioteksrelaterat sammanhang. Meningen i betydelsen: vilken funktion, eller funktioner, begreppet har i den biblioteksrelaterade diskursen; vilka avsikter - uttalade eller outtalade - som ryms i användningen av begreppet. Varför talar man om informationskompetens?

För att göra detta har källmaterialet, fyra inom området relevanta texter, analyserats utifrån ett antal övergripande frågeställningar knutna till användningen av begreppet:

Vilken eller vilka betydelser ges begreppet informationskompetens?

Vilka attityder och föreställningar omger begreppet?

Vilka förväntningar eller förhoppningar knyts till begreppet?

samt:

Utifrån vilka anspråk etableras begreppet informationskompetens i ett bibliotekssammanhang. 


\section{Teoretiska utgångspunkter}

\section{Att läsa texter}

För att undersöka hur begreppet informationskompetens används och utnyttjas i svenska bibliotekssammanhang har alltså ett antal texter där begreppet spelar en central roll studerats. Eftersom textanalys - och val av förhållningssätt till texter - inte är oproblematiskt eller självklart ska de teoretiska utgångspunkter som väglett läsningen redovisas översiktligt.

I sammanhanget har Peter Ekegrens doktorsavhandling The reading of theoretical texts (1995) haft stort in ytande. Han menar att textkritik och -analys inom samhällsvetenskaperna oftast präglas av en naivitet eller en oskuldsfullhet som uppfattar läsningen av vetenskapliga texter som en teorioberoende verksamhet som syftar till att ur texten utvinna dess entydiga mening. Att något sådant inte är möjligt är Ekegrens huvudtes genom hela avhandlingen och han diskuterar den utifrån olika teorier om språk och vad språk är.

En utbredd uppfattning, som han försöker punktera, är den att det finns en grundläggande skillnad mellan litterära och vetenskapliga texter. Litterära texter präglas, hävdas det, av mångtydighet och erstämmighet, medan vetenskapliga texter är enstämmiga och entydiga. Denna uppfattning, att det finns en enhetlig mening att upptäcka i vetenskapliga texter, omöjliggör en framgångsrik tolkning. Resultatet blir istället en tolkning utifrån läsaren som sker på textens bekostnad. (Ekegren, 1995, s. 2 f.)

Vad man måste göra, menar Ekegren, är att acceptera texten som sådan, med alla dess möjliga brister: luckor, självmotsägelser, inkonsekvenser, otydligheter osv. Accepterar vi textens ofullkomlighet blir det också lättare att förstå hur samma text kan ges olika betydelse och mening beroende på vem som läser.

Viktiga uppfattningar när textens betydelsebärande möjligheter avhandlas är för Ekegren, sådana som försöker redogöra för olika relationella aspekter.
Bland annat diskuterar han kontextens betydelse för hur enskilda ord och begrepp kan tolkas. Att enskilda ord och även större textenheter (meningar, stycken osv) ofta får sin mening utifrån sammanhanget, är inte någon kontroversiell ståndpunkt, inte heller att denna kontextuella bestämning kan gå olika långt: Ofta är ett uttryck tillräckligt väl bestämt av sitt sammanhang ("contextualized") för att dess betydelse skall vara tillräckligt klar och entydig - i andra fall inte, då förmår inte sammanhanget råda bot på oklarheter och mångtydighet. När emellertid ett påstående eller textavsnitt, enligt Ekegren, inte förmår kontextualiseras tillräckligt, när det förhåller sig motsägelsefullt och obestämbart i relation till andra påståenden eller textavsnitt kan det bero på att det i själva verket inte kan accepteras av textens dominerande teoribakgrund, utan implicerar eller fordrar ett annat teoretiskt synsätt än det det motsäger. (Ekegren, 1995, s. 168)

En annan uppfattning som också kretsar kring textens relationella aspekter är den om intertextualitet. På ett plan kan man konstatera att "mellantextlighet" är mer påtagligt hos vetenskapliga än några andra texter. Citat, referat, litteraturhänvisningar osv, den rent formella apparaten är i sig en tydlig indikation på hur nära relaterad en vetenskaplig text är till andra och detta är naturligtvis något som Ekegren uppmärksammar. Dessutom påpekar han, utifrån den kontextualitet som diskuterades ovan, att "every quotation, citation etc. that is incorporated into the text /.../ becomes contextualized anew, and will mean something it did not mean before since meaning is context-bound.” (Ekegren, 1995, s. 185)

Peter Ekegrens avhandling är intressant, framförallt är den många gånger klargörande vad gäller grundläggande textteoretiska spörsmål. Däremot behöver man inte instämma i hans slutsats om vad som egentligen är möjligt och inte, när det gäller textkritik och -analys. Ekegrens slutsats, utifrån att ha påvisat teoretiska och vetenskapliga texters mångtydighet och erstämmighet, blir att sökandet efter en sådan texts mening är fåfäng och att det enda som återstår att studera är texternas "meaning producing mecha- 
nisms and structures" (Ekegren, 1995, s. 204). Detta är naturligtvis den självklara slutsatsen om vi med mening förstår den enda slutgiltiga mening en text kan ha. Det är emellertid inte alls självklart, bara utifrån det att vi accepterar att en text är mångtydig och dess mening beroende av sammanhang och läsart. Att det trots detta kan vara meningsfullt att fråga efter en texts mening (eller varför inte meningar) har Ekegren inte motbevisat, däremot har han försett oss med viktiga utgångspunkter för ett sådant arbete. I valet av tillvägagångssätt gäller det alltså att finna vägar som accepterar och understödjer ett sådant synsätt.

\section{Diskursanalys}

En sådan väg erbjuder ett diskursanalytiskt perspektiv, vars själva förutsättning är uppfattningen om texten som del av ett övergripande sammanhang. En grundläggande skillnad i jämförelse med andra vetenskapliga perspektiv, där diskursanalytiska uppfattningar överensstämmer med resonemanget ovan, utgör dessutom uppfattningen om variation. Medan andra synsätt uppfattar variation och avvikelser som någonting problematiskt och försvårande i strävan efter generalitet och konsistens, erkänner diskursanalytiska betraktelsesätt variationer och olika versioner som ett av diskursens kännetecken.

Avgörande för valet av perspektiv för undersökningen, har emellertid den grundläggande uppfattning om språkets konstituerande funktion som formuleras inom diskursanalytisk teori varit, tillsammans med de metodologiska möjligheter som här erbjuder sig.

Att ge en sammanfattande eller entydig bild av vad diskursanalys är låter sig inte göras, helt enkelt därför att det inte existerar en enhetlig diskursanalytisk skola eller teoribildning. Snarare finns det era olika tvärvetenskapliga och multidisciplinära inriktningar, utan någon utbredd enighet sinsemellan när det gäller synen på vad en diskurs är och hur den ska analyseras. Nedan redogörs för vissa grundläggande teoretiska utgångspunkter, som omfattas av era diskursanalytiska inriktningar och som varit vägledande för undersökningen. I stor utsträckning bygger framställningen på Marianne Winther Jørgensens och Louise Phillips' bok Diskursanalys som teori och metod (2000), som erbjuder en pedagogisk och konstruktiv introduktion till diskursanalysens möjligheter.

Strukturalistiska och poststrukturalistiska synsätt är avgörande för diskursanalytisk språkuppfattning: Det är genom språket vi får tillträde till verkligheten (Winther Jørgensen \& Phillips, 2000, s. 15). Vi skapar representationer av verkligheten med hjälp av språket och dessa representationer är aldrig bara speglingar av en redan existerande verklighet, utan de bidrar till att skapa den; det vill säga verkligheten finns naturligtvis "därute" men den ges en mening genom språket - den fysiska världen existerar; och den får sin betydelse genom diskurs. Winther Jørgensen och Phillips (2000, s. 15 f.) exemplifierar detta med hur en översvämning uppfattas. Själva händelsen då vattenståndet i en od stiger och ett landområde översvämmas sker oberoende av människors tankar och tal - den är ett materiellt faktum. När människor sedan försöker formulera sig kring översvämningen, sätta in den i ett meningsgivande sammanhang, kommer den att relateras till - placeras i - olika diskurser. Till exempel en meteorologisk diskurs: översvämningen som ett resultat av ovanligt riklig nederbörd; en politisk diskurs: resultatet av regeringens ovilja att bygga fördämningar; en religiös diskurs: översvämningen som ett utslag av Guds vilja osv.

Språket har alltså inte bara en kommunikativ eller förmedlande funktion utan framförallt så konstituerar det den sociala världen: "Därmed är förändring i diskursen också ett av de sätt på vilka det sociala förändras. Det sker en strid på den diskursiva nivån som bidrar till att både förändra och reproducera den sociala verkligheten.” (Winther Jørgensen \& Phillips, 2000, s. 16)

Vad är då en diskurs? En diskurs kan uppfattas som ett av sammanhanget bestämt sätt att relatera till och uppfatta eller förstå världen eller olika delar av den. Talar man till exempel om folkhälsa utifrån en medi- 
cinsk diskurs skiljer det sig från hur samma begrepp utnyttjas i en politisk diskurs. I stor utsträckning är emellertid frågan om vad som är en diskurs en fråga om avgränsning; att till exempel tala om en politisk diskurs som i exemplet ovan kan visa sig alltför trubbigt eller oanvändbart om man vill studera olika sätt att förhålla sig till begreppet tillväxt; kanske finns det då anledning att tala om t.ex. en miljöpolitisk respektive en marknadspolitisk diskurs. Avgränsningen av diskursen blir alltså snarare en praktisk fråga avhängig frågeställningen.

\section{Avgränsningar och metod}

\section{Avgränsning av diskursen}

I biblioteksrelaterade sammanhang har begreppet informationskompetens diskuterats utifrån olika perspektiv och gentemot olika målgrupper. De sammanhang i vilka denna diskussion förts skulle kunna betraktas som en relativt enhetlig biblioteksdiskurs. Större delen av den diskussion som kretsat kring begreppet har emellertid begränsat sig till informationskompetens inom universitet och högskolor, de har alltså förts inom universitets- och högskolebibliotekens institutionella sammanhang. Dit hör också undersökningens urval av källor. Därigenom kan diskursen avgränsas ytterligare och samtidigt placeras in i större sammanhang, övergripande diskurser: Utifrån diskussionen ovan angående avgränsning av diskurser som en analytisk operation - grundat på undersökningens behov - har en högskolebiblioteksdiskurs, identifierats vilken är del av såväl en universitets- och högskolerelaterad diskurs som en övergripande biblioteksdiskurs.

\section{Urval av källmaterial}

Utifrån ett diskursanalytiskt perspektiv, där det gäller att noggrant fokusera texter utifrån hur betydelser och uppfattningar etableras och konstitueras, finns ofta anledning att omsorgsfullt begränsa materialet för att göra det tillräckligt hanterligt för en grundlig genomgång (Wood \& Kroger, 2000, s. 80 f.). Samtidigt är det naturligtvis viktigt att göra ett representativt och för frågeställningen fruktbart urval, vilket förhoppningsvis har åstadkommits med föreliggande källmaterial. De texter som bildar underlag för undersökningen, vilka får en utförligare presentation i samband med min redogörelse för textanalysen nedan, är Jan Hagerlids Studenternas bibliotek (slutrapport från BIBSAM, 1996); Biblioteksbarometer 2000 (2001) sammanställd av Åsa Lindberg-Sand; Agneta Lantz' föredrag vid Nordiska Vetenskapliga Biblioteksföreningars Förbunds (NVBF) konferens Informationskompetens och Användarutbildning, "Informationskompetens - ett centralt utbildningsmål för den högre utbildningen" (1997) samt Boel K. Gustafssons magisteruppsats Informationskompetens - ett nytt mål för den högre utbildningen? (1998).

\section{Tillvägagångssätt}

I avsikt att uppmärksamma olika teman och tolkningsmöjligheter och för att se vilka konsekvenser de får för hur begreppet informationskompetens kommer att uppfattas, hur det konstitueras, har en analyserande närläsning av källtexterna gjorts. Av utrymmesskäl har det varit nödvändigt att kraftigt komprimera redovisningen av textanalysen, något som oundvikligen begränsar läsarens möjlighet att själv värdera tolkningsarbetet. För en fylligare redogörelse hänvisas emellertid till författarens magisteruppsats (Eld, 2001) som finns tillgänglig i fulltext online. Viktigt att påpeka, för att återknyta till vad som sagts ovan i sammanhanget, är att denna tolkning naturligtvis inte ska uppfattas som den slutgiltiga eller den enda möjliga; snarare får man se den som ett förslag på läsning - ett slags provisorium. Vidare har de iakttagelser textanalysen givit studerats utifrån ett diskursanalytiskt perspektiv, i anslutning till att resultaten av detta presenteras redogörs även för de begrepp och analysverktyg som då utnyttjats.

\section{Texterna:}

\section{Studenternas bibliotek - BIBSAM:s slutrapport Sammanhang och målgrupp: Slutrapporten Stu- denternas bibliotek}

Rapporten, som som presenterades i januari 1996, satte punkt för ett utredningsarbete som pågått sedan 
1994. Underlag för slutrapporten var fyra sammanhängande delstudier som dessförinnan hade dokumenterats i lika många rapporter. Utredningsarbetet samordnades av Jan Hagerlid, BIBSAM, som också skrev slutrapporten. BIBSAM är Kungliga bibliotekets (Sveriges nationalbibliotek) avdelning för nationell samordning och utveckling: "BIBSAM: s huvuduppgift är att förbättra och effektivisera informationsförsörjningen till högre utbildning och forskning." (BIBSAM, 2003)

Utredningen redogjorde för de senare årens utveckling vid universitets- och högskolebiblioteken och relaterade denna till i första hand studenternas behov. Viktiga faktorer i sammanhanget var, menade man, informationsteknikens snabba utveckling, en dramatisk ökning av antalet studenter och pedagogisk förnyelse inom högskolan. Avsikten med utredningsarbetet var att ge ett underlag för beslut i biblioteksfrågor såväl lokalt - vid de enskilda universiteten och högskolorna - som centralt - vid Kungliga biblioteket, BIBSAM, olika högskolemyndigheter och på regeringsnivå. Utifrån denna målsättning kan man konstatera att företrädare för hela universitets- och högskolevärlden uppfattades som den tilltänkta målgruppen, i synnerhet företrädare på beslutsfattande nivå.

Definition av begreppet - tre kriterier: På ett par ställen i BIBSAM-rapporten, ges näst intill identiska beskrivningar av informationskompetens, beskrivningar som kan uppfattas som definierande begreppet och som har haft stort in ytande på den aktuella diskursen. Ofta hänvisas det till rapporten som den text som introducerade begreppet informationskompetens i Sverige. Här ges tre kriterier för vad informationskompetens innebär: förmågan att söka, kritiskt värdera och kreativt utnyttja information (Hagerlid, 1996, s. 19, s. 48).

Ur ett biblioteksperspektiv skulle man kunna säga att det första, förmågan att söka information, är tämligen okomplicerat eller etablerat. Det är något man i princip alltid arbetat med att lära ut vid biblioteken.
Att kritiskt värdera information är något som låter sig göras på era olika plan. Den kan ifrågasättas utifrån ett källkritiskt perspektiv där man ställer sig frågor som varifrån informationen kommer och i vilket syfte den har producerats. Informationen kan granskas utifrån ett mer innehållsligt perspektiv, dvs. utifrån de kunskaper man sedan tidigare har i ämnet. Detta förutsätter naturligtvis en viss förtrogenhet med ämnet och ofta rena fackkunskaper.

Att kreativt utnyttja information kan innebära en mängd olika saker varav de viktigaste skulle kunna vara att omsätta informationen i kunskap och att kommunicera den vidare. I synnerhet den förra av dessa aktiviteter förutsätter en intellektuell eller kognitiv förmåga. Oavsett vilken kunskapssyn man har tror jag att de esta menar att för att kunna säga att man kan någonting - äger en viss kunskap - förutsätts man ha en särskild förståelse av detta något. Också för att kunna vidarebefordra information på ett meningsfullt sätt krävs en viss förståelse för vad det är för slags information; i vilka sammanhang den ingår och på vilket sätt den är av betydelse.

Den relativt vida beskrivningen etablerar informationskompetens som något som förutsätter både ämnesrelaterade kunskaper och intellektuell förmåga. Av de tre kriterierna är det egentligen bara det första, förmågan att söka information, som direkt relaterar till bibliotek och biblioteksverksamhet. Även om bibliotekarier ofta har särskilda kunskaper vad gäller viss slags källkritik är båda de senare kriterierna, att kritiskt värdera och kreativt utnyttja information, huvudsakligen en fråga för ämnesanknuten undervisning, dvs. inte något som generellt uppfattas som en uppgift för biblioteken.

Informationskompetens som mål för universitet och högskola: Beskrivningarna som refereras ovan formuleras i direkt anslutning till idén om informationskompetens som ett uttalat mål för universitet och högskolor. Utifrån detta ter det sig tämligen naturligt att de är förhållandevis generella eller brett formulerade. Rapporten och i synnerhet dess förslag och rekommendationer riktar sig till företrädare - framför 
allt beslutsfattare - inom universitet och högskolor. Att i sammanhanget tynga begreppet med en mer specifik och detaljerad redogörelse för vad det kan innebära skulle kunna få företrädare utanför biblioteksvärlden att rygga, särskilt kanske om en sådan redogörelse skulle utveckla ett mer biblioteksinriktat perspektiv.

Informationskompetensen som mål relaterat till bibliotekens betydelse: I rapportens utredande text knyts förvisso förekomsten av informationskompetens som ett uttalat mål i olika styrdokument samman med bibliotekens förekomst i samma slags dokument och på så vis etableras trots allt begreppet som biblioteksrelaterat (Hagerlid, 1996, s. 22). Finns informationskompetens inskrivet i måldokumenten innebär det att också biblioteken gör det, om också implicit. Konkreta förslag angående bibliotekens förekomst i olika styrdokument formuleras emellertid i rapporten ganska återhållsamt (Hagerlid, 1996, s. 48). Därigenom framställs bibliotekens betydelse för högskolan trots allt som en smula underordnad.

Inlärningsprocess och kunskapsgenerering: Under rubriken "Grundläggande ställningstaganden" relateras begreppet informationskompetens direkt till engelskans information literacy, samtidigt utvecklas den ovan diskuterade beskrivningen av vad informationskompetens är (Hagerlid, 1996, s. 43). Dock finns det en viss tveksamhet eller moderering i texten som är viktig att uppmärksamma: Aktiviteter relaterade till mer ämnesanknuten undervisning framhålls, aktiviteter som är av avgörande betydelse för kunskapsinlärning rent generellt, samtidigt som mer biblioteksnära verksamhet ges underordnad betydelse och vikten man tillmäter dessa reduceras. Ett en smula problematiskt förhållningssätt till innebörden av begreppet informationskompetens kommer i dagen - åtminstone utifrån ett biblioteksperspektiv. Samtidigt som stycket rymmer viss tveksamhet inför vikten av vad som konstateras, framställs kunskapsgenerering som begreppets mest väsentliga innebörd - detta på bekostnad av mer biblioteksanknuten verksamheter.
Informationskompetens för framtiden och livslångt lärande: Ett sätt att motivera behovet av informationskompetens är alltså att relatera det till diskussioner om lärande mer generellt. I stycket ovan refererades till en beskrivning av begreppet som lika gärna kunnat vara en beskrivning av t.ex. begreppet kunskapsinhämtning. I rapportens motiveras behovet av informationskompetens även såsom varande centralt för det livslånga lärandet (Hagerlid, 1996, s. 43). Därigenom kommer begreppet att förknippas med ett av samtidens mest potenta koncept. Ur ett samhälleligt perspektiv är det få företeelser som kan konkurrera med detta när det gäller aktualitet och allmän spridning. Det livslånga lärandet förekommer i en mängd olika diskurser - politiska, pedagogiska, samhällsekonomiska, akademiska osv. - och i många sammanhang ses det som både en möjlighet och en förutsättning för framtida utveckling och framgång; såväl på ett individuellt som på ett samhälleligt plan. Samtidigt relateras resonemanget till föreställningar om den snabba kunskapsutvecklingen och den rörliga arbetsmarknaden vilket ger det en särskild legitimitet i och med att dessa föreställningar har fått oerhört stark genomslagskraft i det allmänna medvetandet.

Dessa föreställningar medverkar också till att skapa ett framtidsinriktat perspektiv. I samma stycke hänvisas också till "ett mer självstyrt och individualiserat lärande". Utan att egentligen ta ställning till existerande förhållanden kommer detta att framstå som den riktning den pedagogiska utvecklingen har, ordet mer implicerar en förändring: mer än nu; mer än tidigare. Utifrån denna mycket kortfattade hänvisning till förändrade lärprocesser etableras "förmågan att tillvarata information som avgörande för en hög utbildningskvalitet".

Bibliotekens roll och lärarnas: Under "Grundläggande ställningstaganden" diskuteras hur "målen om höjd informationskompetens" ska nås (Hagerlid, 1996, s. 44). I resonemanget etableras biblioteken som en förutsättning för informationskompetensens befordran. Dessutom relateras hela idén till "bibliotekets integration i den pedagogiska processen". 
Denna framställs som en positiv, pågående utveckling som dock är långt ifrån målet.

En förutsättning för att nå detta mål är att "biblioteken ses som utbildningsinstitutioner snarare än serviceinrättningar". Det handlar alltså om en avgörande förändring i synen på vad bibliotek är, det är inte frågan om ytterligare en uppgift, eller att bara skapa en ökad förståelse för bibliotekens pedagogiska verksamhet. De måste betraktas som utbildningsinstitutioner inom en värld av utbildningsinstitutioner (högskolan) dvs. som en jämbördig partner inom utbildningsverksamheten. Detta sätts också i kontrast till biblioteken som serviceinrättningar, ett uppdrag som får en smula pejorativ eller nedsättande klang: en institution har naturligtvis högre status än en inrättning och att ansvara för utbildning är naturligtvis mer betydelsefullt än att bara ge service.

Samtidigt förutser man kanske ett visst motstånd mot denna förändring i synsätt hos andra yrkesgrupper inom universitet och högskolor. Lärarna skulle kunna opponera sig mot tanken på bibliotekarierna som likvärdiga i den pedagogiska processen och dessutom vara ovilliga att avstå från den service man förväntar sig från bibliotekshåll. Därför är det viktigt att göra dem delaktiga i den eftersträvansvärda utvecklingen; samarbetet med dem uppmärksammas som avgörande i sammanhanget. Lärarna måste dessutom "ta en väsentlig del av ansvaret för studenternas informationskompetens". Härigenom identifieras lärarna i sammanhanget som en betydelsefull yrkesgrupp när det gäller bibliotekens utveckling och befrämjandet av informationskompetens.

BIBSAM:s slutrapport - sammanfattande iakttagelser: Rapporten ger inte utrymme för några mer detaljerade beskrivningar av vad informationskompetens kan tänkas vara. Istället formuleras tämligen vida redogörelser för begreppet. Dessa redogörelser tycks dessutom lägga huvudvikten av vad som fordras för att befrämja informationskompetens vid företeelser som egentligen ligger utanför bibliotekens ansvarsområden. Snarare är det den ämnesanknutna undervisningen och de ordinarie lärarna som har huvudansvaret för att göra studenterna informationskompetenta. Samtidigt beskrivs informationskompetens i texten som något som är av avgörande betydelse ur ett brett samhällsperspektiv och inte bara är en angelägenhet för biblioteks- och högskolevärlden.

Ändå ses biblioteken som en förutsättning för att nå målet informationskompetens och de måste därför integreras $\mathrm{i}$ universitetens och högskolornas pedagogiska processer. De måste betraktas som utbildningsinstitutioner i stället för serviceinrättningar. Även i detta sammanhang uppmärksammas universitets- och högskolelärarna som en viktig grupp: att involvera och göra dem delaktiga i de förändringsprocesser som målas upp i rapporten framstår som avgörande för möjligheten att nå målen.

\section{Biblioteksbarometer 2000 - en studie av använd- ning och erfarenheter av Lunds universitets bib- liotek}

Sammanhang och målgrupp: Biblioteksbarometern tillkom för att vara ett stöd för universitetets utveckling av biblioteksorganisationen och är en del av hela universitetets kvalitetsarbete. Studien riktade sig till såväl biblioteksorganisationen som ansvariga på fakultets- och institutionsnivå. Biblioteksbarometerns syfte var bl.a. att utifrån biblioteksorganisationen som helhet undersöka "hur tillfredsställda de olika användargrupperna är med sin egen kompetens i informationssökning" (Lindberg-Sand, 2001, s. 8) något som naturligtvis kan relateras till informationskompetens, vilket också görs i studien.

Informationskompetens som kompetens i informationssökning: Ett stycke ned på samma sida som citatet ovan hämtats från, formuleras (en del av) syftet som att kartlägga "användarnas bedömning av egen informationskompetens". Vad som sker är alltså att det i princip sätts likhetstecken mellan kompetens $i$ informationssökning och informationskompetens. Detta kan uppfattas som en relativt begränsad syn på vad informationskompetens innebär men är naturligtvis beroende av vad man menar ryms i den första 
formuleringen. Det tycks emellertid vara tämligen ofrånkomligt att själva sökprocessen ses som det grundläggande eller mest betydelsefulla.

Att bedöma egen informationskompetens: Användarnas bedömning av den egna informationskompetensen har gått till så att det i det frågeformulär man använt för undersökningen av alla de frågeställningar som ingår i barometern, funnits ett särskilt avsnitt rubricerat "Egen informationskompetens" (Lindberg-Sand, 2001, s. 89 (bil. 1, s. 9)). Användarna ombads dels värdera ett antal färdigheter och dels bedöma i hur hög grad de själva besatt dessa. Utifrån hur frågan är formulerad kan man konstatera att informationskompetens relateras till två huvudsakliga färdigheter: "att söka litteratur och använda biblioteken". Förutom att behålla fokus på informationssökning blir alltså begreppet direkt kopplat till biblioteksverksamhet och det i en synnerligen vid formulering: att använda bibliotek.

Av de elva färdigheter som användarna förväntades ta ställning till var nio relaterade till informationssökning, alla utom en av dessa hade dessutom en koppling till biblioteket. Att begreppet informationskompetens sammankopplas så påtagligt med konkreta bibliotekssituationer kan kanske förklaras utifrån studiens syfte. Inte desto mindre kommer det att $\mathrm{i}$ texten etablera informationskompetens som någonting synnerligen biblioteksberoende.

Bibliotekens roll och lärarnas: En uppfattning om bibliotekens och lärarnas gemensamma ansvar för att utveckla informationskompetens hos studenterna löper mer eller mindre uttalat genom hela studien. Det är emellertid i första hand på biblioteken denna kompetensutveckling kan ske (Lindberg-Sand, 2001, s. 12). Överhuvudtaget andas studien en viss skepsis inför lärarnas förmåga eller vilja att engagera sig i utvecklingen av studenternas informationskompetens. Vad deras förmåga anbelangar befarar man att den informationskompetens lärare/forskare byggt upp inte alltid överensstämmer med vad de behöver bibringa studenterna (Lindberg-Sand, 2001, s. 12). I sammanhanget formuleras ett par intressanta aspekter. Dels på informationskompetensens natur som sådan: Den är i så hög grad situations- och sammanhangsberoende att en forskare inom ett område inte kan förväntas besitta relevant kompetens för de studenter hon eller han undervisar. Dels på lärares/ forskares intresse av att utveckla den egna informationskompetensen: De förutsätts i första hand göra detta för att underlätta sin egen forskning - det pedagogiska ansvaret förväntas de inte ta lika allvarligt.

Lärarnas vilja att engagera sig i studenternas utveckling av informationskompetens ses alltså, utifrån deras dubbla roller som både lärare och forskare, med viss skepsis. Exempelvis refereras till en annan universitetsövergripande undersökning ("barometer") riktad till just lärare och forskare vilken skiljer sig från andra "barometrar" i det att den totalt saknar biblioteksrelaterade frågor. Detta uppfattas naturligtvis som så mycket mer besvärande som företrädare för respektive målgrupp formulerat frågorna (Lindberg-Sand, 2001, s. 72). Utifrån resonemanget ovan är det inte förvånande att studien formulerar en bekymrad slutsats vad gäller samarbetet mellan bibliotek och lärare:

För det tredje framstår lärarnas relation till biblioteken - inom ramen för de pedagogiska uppgifter det innebär att medverka till studenternas utveckling av informationskompetens - som ett sorgligt försummat kapitel. (Lindberg-Sand, 2001, s. 73)

Informationskompetens och lagen: Intressant är att Biblioteksbarometer 2000 inte finner det betydelsefullt att explicit formulera någon egentlig beskrivning av vad informationskompetens innebär eller vad som ryms i begreppet. Desto mera så eftersom en viktig målgrupp - den utanför biblioteksorganisationen - förmodligen inte kommit i kontakt med uttrycket i någon större utsträckning tidigare. Snarare är det så att texten, genom att oproblematiskt och återkommande referera till informationskompetens, kommer att etablera begreppet som någonting själv- 
klart, vars innebörd förutsätts vara tämligen entydig och konkret.

Ett exempel på detta är när texten formulerar sig kring informationskompetens som det studenterna jämte ett kunnande ska förvärva under sina studier - det kommer alltså att uppfattas som ett grundläggande utbildningsmål - föreskrivet enligt högskolelagen (Lindberg-Sand, 2001, s. 12). Det är svårt att uppfatta formuleringen som något annat än en objektiv redogörelse för vad högskolelagen föreskriver om informationskompetens. Studerar man lagen måste man emellertid konstatera att begreppet där lyser med sin frånvaro. I 1 kap. 9 § av högskolelagen beskrivs ett antal förmågor vilka, beroende på vad man lägger in i begreppet, det är möjligt att relatera till informationskompetens (Högskolelag, SFS nr: 1992:1434). Det intressanta är emellertid avsaknaden av en sådan vidareutveckling av resonemanget; att man väljer att kort och gott hänvisa till lagtexten utifrån en formulering om informationskompetens som någonting som är ett krav i dagens grundläggande högskoleutbildning. Texten etablerar alltså informationskompetens som någonting föreskrivet i lag.

Biblioteksbarometer 2000 - sammanfattande iakttagelser: I studien återkommer begreppet informationskompetens ett stort antal gånger. Det har dessutom fătt en egen avdelning i den enkät som utgör studiens underlag. Trots detta redogörs aldrig explicit för vad som avses med eller ryms i begreppet. I stället formulerar man sig kring begreppet på ett sådant sätt att det framstår som allmängods: texten etablerar informationskompetens som någonting välkänt och oproblematiskt, vars betydelse är klar och entydig och inte kan missförstås.

Utifrån sammanhangen framträder emellertid tre olika attribut som kan relateras till informationskompetens: det föreskrivs som mål för grundläggande högskoleutbildning enligt Högskolelagen; det är biblioteksberoende och det handlar framför allt om - eller kan rent av vara samma sak som - kompetens i informationssökning. Det är på biblioteken de främsta förutsättningarna finns för att bibringa studenterna adekvat informationskompetens. Biblioteken har emellertid inte ensamt ansvaret för detta utan det måste ske i samarbete med lärarna, något som dock hitintills, dessvärre, inte har fungerat.

\section{Informationskompetens - ett centralt utbildnings- mål för den högre utbildningen: Agneta Lantz fö- redrag vid NVBF:s konferens i Linköping 1996}

Sammanhang och målgrupp: 1996 arrangerade Nordiska Vetenskapliga Biblioteksföreningars Förbund (NVBF) och Linköpings universitetsbibliotek konferensen Informationskompetens och användarutbildning. Avsikten var att i ett nordiskt sammanhang skapa en möjlighet att diskutera informationskompetens och bibliotekens pedagogiska uppgifter vad gäller användarutbildning. Målgruppen måste i första hand uppfattas ha varit företrädare för biblioteksvärlden - i synnerhet sådana med kopplingar till universitets- och högskolebibliotek - i hela Norden. Agneta Lantz föredrag, som gavs under den övergripande rubriken "Informationskompetens - information literacy - ett uttalat utbildningsmål", är ett synnerligen engagerat och på många sätt tankeväckande inlägg.

Kunskap och information: Återkommande i föredraget sker en sammankoppling - rent av sammanblandning - av information med kunskap. Detta resulterar i att en förenklad syn på kunskap och relationen mellan kunskap och information formuleras. Utan att behöva ge sig in i ett mer avancerat epistemologiskt resonemang finns det anledning att uppmärksamma en begreppsförvirring som kan vara särskilt bekymmersam i just det här sammanhanget. När man diskuterar begreppet informationskompetens, som rymmer uppfattningar om såväl informationshantering som kunskapsgenerering, finns anledning att vara särskilt försiktig i användandet av de olika begreppen.

Den informationskompetentes handlingar: Ett i den internationella litteraturen återkommande sätt att försöka beskriva informationskompetens är att 
räkna upp ett antal attribut eller egenskaper som man menar att den informationskompetente personen måste besitta. Så gör också Agneta Lantz under rubriken "Informationskompetens - grunden för livslångt lärande"; uppenbart inspirerad av Christina S. Doyles definition av information literacy (Doyle, 1994, s. 2 f). Vad som beskrivs är inte kunskaper; utan den informationskompetente personen identifieras utifrån sina handlingar - vad personen gör. Snarare än en redogörelse för färdigheter handlar det om en normativ beteendebeskrivning (Lantz, 1997, s. 2). Beskrivningarna rör sig på vad man skulle kunna kalla två olika kunskapsplan. Dels ett där aktiva handlingar som man måste utföra för att anses informationskompetent beskrivs - ett slags hantverksdimension. Dels ett där Lantz redogör för en förståelse, ett grundläggande synsätt som måste omfattas av personen för att denne ska kunna betraktas som informationskompetent: Den informationskompetente personen måste besitta en djup förståelse (insikt) för informationens avgörande betydelse för att fatta "kloka beslut".

Den informationskompetente identifieras alltså som en person som dels omfattar ett visst synsätt vad gäller information och beslutsfattande och dels utför vissa specifika handlingar - agerar i enlighet med ett specifikt beteendemönster.

Informationskompetens - en livsnödvändig förmåga: I föredraget vidgas beskrivningen av den informationskompetente individen till att också omfatta mer generella karaktäristika. Han eller hon framställs som en person som besitter en mängd betydelsefulla egenskaper och karaktärsdrag (Lantz, 1997, s. 3). Även att ta ansvar "för sitt eget lärande" och att delta i "informella kontaktnätverk" blir en del av informationskompetensen. Den informationskompetente karaktäriseras som produktiv och målinriktad: "Man söker information för problemlösning och beslutsfattande" och "använder en arsenal av effektiva strategier för att hålla jämna steg med utvecklingen". Ordvalen och formuleringarna skapar bilden av en synnerligen kompetent person, en person vars kompetens inte begränsas till informationshantering, utan är mycket mer omfattande än så. Utan informationskompetens riskerar man däremot att stå sig slätt eftersom det "är en livsnödvändig förmåga i informationsåldern" (Lantz, 1997, s. 8).

Därigenom etableras informationskompetens som någonting som dels ger individen stora förutsättningar att nå framgång och utvecklas och dels är absolut nödvändigt - livsnödvändigt - för varje individ som överhuvudtaget vill kunna hävda sig i dagens och morgondagens samhälle.

Informationskompetens som mål för all utbildning: Under rubriken "Informationskompetens - ett nyckelmål för den högre utbildningen" argumenteras för informationskompetensens utbredning utifrån ett samhälleligt perspektiv, bl a. åberopas statliga utredningar inom utbildningsområdet. Att föra in informationskompetens som ett mål för utbildningen blir en fråga om att uppmärksamma "samhälleliga krav" (Lantz, 1997, s. 3 f). Återigen motiveras informationskompetens utifrån uppfattningen att detta är någonting som krävs för att nå framgång - i det här fallet också relaterat till "optimal konkurrenskraft" - och det är samhällets ökade krav på "kvalitet och effektivitet" som fordrar denna förmåga hos de examinerade studenterna. Samtidigt begränsas inte ansvaret för informationskompetensens befrämjande till den högre utbildningen utan den måste bli "ett uttalat mål för all utbildning", ett mål som ska "genomsyra samtliga utbildningsstadier från grundskolenivå till universitets- och högskolenivå”.

I texten etableras kravet på informationskompetens inte enbart eller i första hand som ett krav relaterat till studenternas undervisningssituation på universitet och högskolor, utan framstår som än mer betydelsefullt. Informationskompetensens utbredning kommer att uppfattas som av avgörande betydelse för hela samhällsutvecklingen och vår gemensamma möjlighet till konkurrenskraft och framgång.

Nya lärprocesser: Utifrån resonemanget ovan om informationskompetensen som uttalat mål för all utbildning dras i föredraget slutsatsen att undervis- 
ningens former måste ifrågasättas: "Vi behöver därför se över undervisningsprocesserna som helhet $\mathrm{i}$ utbildningssystemet" (Lantz, 1997, s. 4) konstateras det och särskilt intressant i det här fallet är vilka vi är. Med tanke på sammanhanget är det svårt att se att $v i$ identifierar några andra än yrkesgruppen bibliotekarier - rent av begränsad till bibliotekarier vid universitets- och högskolebibliotek. Utifrån ett sånt perspektiv är det intressant att re ektera över vilka anspråk man gör: "För att nå målet, informationskompetenta studenter /.../ bör därför traditionella undervisningsformer ersättas med lärprocesser där informationssökning och informationsutnyttjande /.../ står i centrum.” (Lantz, 1997, s. 4 f)

Vad som sker i texten är att det - utifrån bibliotekarierollen - propageras för omfattande pedagogiska förändringar inom utbildningssystemet. Dessutom sker detta samtidigt som målet för dessa förändringar formuleras, nämligen informationskompetensens befrämjande. Det är alltså de nya pedagogiska initiativen som är viktiga för informationskompetensen, inte informationskompetensen som är en del av eller något som understödjer nya pedagogiska initiativ.

Bibliotekens och bibliotekariernas roll: Att också bibliotekens och bibliotekariernas roller förändras i och med att informationskompetens tillmäts en så fullkomligt avgörande roll ter sig ganska självklart. Det är inte bara en fråga om att delta $i$ utbildningen utan i lika hög grad en fråga om att "aktivt medverka till" att denna utbildning kommer till stånd; något som egentligen är tämligen uppenbart utifrån den kraftigt propagerande tonen i texten (Lantz, 1997, s. 5). Kanske kan också bevekelsegrunderna för ett så aktivt agiterande komma att ifrågasättas. Bibliotek och bibliotekarier sägs gå en "viktig och in ytelserik" framtid till mötes, något som åtminstone utanför biblioteksvärlden skulle kunna uppfattas som den egentliga orsaken till det kraftfulla engagemanget. Samtidigt är det i texten uppenbart att engagemanget är en förutsättning för att målet ska kunna nås. Trots att informationskompetens framställs som någonting oundgängligt för framtiden - någonting som alla, ur ett brett samhälleligt perspektiv, borde vara intresserade av att förverkliga - fordras en stor ansträngning från bibliotekens sida för att driva utvecklingen i rätt riktning (Lantz, 1997, s. 6).

Informationskompetens etableras i texten inte bara som ett centralt utbildningsmål för den högre utbildningen utan ges, som vi sett ovan, mycket vidare implikationer än så. Dess betydelse får följaktligen konsekvenser för i princip allt biblioteksarbete:

Bibliotekarierna själva behöver ta sin pedagogiska roll på allvar och låta den genomsyra allt biblioteksarbete. Den pedagogiska rollen rör inte endast undervisningssituationer utan i lika hög grad det dagliga referensarbetet. Varje möte med studenter, lärare forskare och andra kunder är viktiga pedagogiska situationer med målet informationskompetens i sikte. (Lantz, 1997, s. 6)

Agneta Lantz föredrag - sammanfattande iakttagelser: I föredraget identifieras den informationskompetente individen som någon som besitter särskilda egenskaper och karaktärsdrag och som agerar utifrån ett särskilt beteendemönster. Dessa olika företeelser sammantagna ger individen stora förutsättningar att utvecklas och nå framgång, medan däremot avsaknaden av dem utesluter samma framtidsmöjligheter. På motsvarande vis etableras informationskompetens som en förutsättning för samhällelig utveckling och konkurrenskraft. Målet - informationskompetensens utbredning - blir med andra ord en vision vars genomförande är av avgörande betydelse för samhället som helhet.

Därför är det också nödvändigt att driva den pedagogiska utvecklingen i en riktning som tar hänsyn till och uppskattar informationskompetens som ett centralt mål för undervisningen. Biblioteken och bibliotekarierna ges en avgörande betydelse för att de eftersträvansvärda målen ska kunna uppnås, en betydelse som också kommer att medföra en in ytelserik framtid: För att nå dit fordras emellertid en mobilisering och ett engagemang från bibliotekarierna, som måste låta dessa strävanden efter informationskompetensens utbredning genomsyra så gott som allt biblioteksarbete. 
Informationskompetens - ett nytt mål för den högre utbildningen? - Boel K. Gustafssons magisteruppsats

Sammanhang och målgrupp: Boel K. Gustafsson presenterade sin magisteruppsats på vårterminen 1998 vid Institutionen för kultur- och biblioteksstudier vid Uppsala universitet. Uppsatsens huvudfrågeställningar formulerades på följande vis: "1. I vilken omfattning är informationskompetens idag ett uttalat mål för universitet, högskolor och deras respektive bibliotek? 2. Har forskningsbiblioteken förstärkt insatserna för bibliotekariernas pedagogiska utveckling?" (Gustafsson, 1998, s. 5)

Med företrädare för biblioteks- och informationsvetenskap som främsta målgrupp studeras i uppsatsen vilket genomslag föreställningen om informationskompetens fått inom universitets- och högskolevärlden, som det kan utläsas av de studerade dokumenten. Bland annat utifrån detta formuleras iakttagelser om bibliotekens möjligheter och tänkbara strategier inför framtiden.

Informationskompetens - vidlyftiga beskrivningar: I uppsatsen görs en omsorgsfull och bred genomgång av diskussionen kring informationskompetens och hur man försökt beskriva vad begreppet egentligen står för. I stor utsträckning är det den omfattande amerikanska debatten som får uppmärksamhet. Utifrån denna tämligen grundliga genomgång uppmärksammas också en del problematiska förhållanden när det gäller användningen av begreppet. Gustafsson ger uttryck för tveksamhet inför de ibland nästan allomfattande, eller "vidlyftiga och nästan magiska", beskrivningar av informationskompetens som förekommer (Gustafsson, 1998, s. 14). Att informationskompetensen skulle spela en så avgörande roll för den framtida samhällsutvecklingen som utmålats i olika sammanhang kan, menar hon, vara svårt att acceptera.

Denna ambivalens utvecklas emellertid inte. Istället går argumentationen i motsatt riktning utifrån samhällets föränderlighet och föreställningen om informations- eller kunskapssamhällets avgörande betydelse för utvecklingen. Härigenom återförs informationskompetensen implicit till den exceptionella position hon tidigare tycktes opponera sig emot. De vidlyftiga och nästan magiska beskrivningarna av informationskompetens kan ingalunda avfärdas som ovederhäftiga, utan äger åtminstone ett visst berättigande.

Informationskompetens - ett begrepp att utveckla: I uppsatsens summering av diskussionen kring begreppet prioriteras ingen uppfattning om vad informationskompetens innebär framför andra. Istället konstateras att den amerikanska debatt och kritik som omgett begreppet information literacy även är relevant för den svenska motsvarigheten. Samtidigt hävdas uppfattningen att begreppet bör ges tydliga definitioner inom den svenska biblioteksvärlden (Gustafsson, 1998, s. 20). Det konstateras också, mer eller mindre uttalat, att en utveckling av begreppet informationskompetens är nödvändigt om det ska kunna ges den framskjutna och betydelsefulla position som eftersträvas inom biblioteksvärlden: Det är en fråga om att - utifrån ett biblioteksperspektiv - kunna "hävda informationskompetensen som begrepp", det vill säga som något vederhäftigt och relevant, som något av substantiell betydelse.

Informationskompetens - bibliotekens integration $i$ högskoleutbildningen: Även om uppsatsen inte helt tar avstånd från uppfattningar om informationskompetensens avgörande betydelse för hela samhällsutvecklingen, behåller den fokus på dess relevans för universitets- och högskoleutbildningen. Det är i dessa sammanhang man måste se kraven på informationskompetens, vilka, konstaterar Gustafsson, handlar om "bibliotekens integration i den övriga högskoleutbildningen" (Gustafsson, 1998, s. 20). Krav som formuleras inne på biblioteken men som riktar sig mot den övriga högskolevärlden. Biblioteken har dessutom all anledning till att föra fram dessa krav eftersom det bl.a. är högskolans egen pedagogiska utveckling - i uppsatsen representerad av PBL (problembaserat lärande) - som förser biblioteken med argumenten. Biblioteken ges 
alltså uppgiften att tala om för lärare och pedagoger inom universitet och högskolor vilka behov deras undervisningsformer för med sig. Samtidigt är det viktigt att notera att det är en fråga om att göra lärare uppmärksamma på en kompetens som gagnar deras undervisningsformer, en färdighet som befrämjar deras sätt att utbilda studenterna.

Pedagogikens avgörande betydelse: Frågan om informationskompetens knyts gärna till pedagogiska resonemang, där kopplingen mellan begreppet och en viss form av undervisning är mer eller mindre avgörande. I Gustafssons uppsats görs denna koppling särskilt stark - PBL ses i princip som en förutsättning för informationskompetens - intressant är hennes formulering i sammanhanget, att informationskompetens "är ett vederhäftigt begrepp som tydliggör behovet av biblioteket som en pedagogisk resurs" (Gustafsson, 1998, s. 79).

Tidigare i uppsatsen etablerades informationskompetens som ett på sätt och vis ofärdigt begrepp; ofärdigt i så måtto att det måste utvecklas för att kunna utnyttjas utåt, som ett begrepp som med pregnans kan användas av biblioteken för att hävda sin egen betydelse. Kontradiktionen är emellertid inte så stor om man ser till sammanhanget: Återigen är det avhängigheten av en viss pedagogik som är avgörande. I ett PBL-sammanhang är möjligheterna att hävda bibliotekens och informationskompetensens betydelse oerhört mycket större än utan denna koppling. Konsekvensen blir emellertid att begreppet knyts så hårt till den bestämda undervisningsformen att det inte kan frigöra sig: PBL blir verkligen en förutsättning för att nå informationskompetens. Samtidigt konstateras emellertid att framtiden hör PBL till, varigenom risken med ett sådant ställningstagande reduceras. Att relatera eller knyta idén om informationskompetens till företeelser som förutspås bli av stor betydelse i framtiden är ett återkommande tema i diskursen.

Lärarnas betydelse för informationskompetensen: I och med att informationskompetens så hårt knyts till en särskild undervisningsform blir naturligtvis lärarna och deras ställningstagande av avgörande betydelse. Det fordras att de använder sig av undervisningsformer som befrämjar informationskompetens; frågan är då hur man från bibliotekens sida ska kunna förvissa sig om detta. Att bibliotekarierna på egen hand ska kunna förändra lärares undervisningsmetoder, hur väl man än argumenterar eller propagerar för informationskompetens ses inte som realistiskt, utan det fordras en dialog, "en gemensam debatt" (Gustafsson, 1998, s. 79). Det kan uppfattas som en självklarhet men det är betydelsefullt att uppmärksamma eftersom det annars ofta handlar om hur bibliotekarierna - av egen kraft - ensamma skall driva frågan om informationskompetensens befordran.

Boel K. Gustafssons magisteruppsats - sammanfattande iakttagelser: Trots en ansats att fjärma sig från de föreställningar som ger informationskompetensen en grundläggande betydelse för i princip all samhällsutveckling, accepteras i texten att dessa åtminstone äger viss relevans. Ska man kunna utnyttja begreppet i bibliotekssammanhang för att få gehör för sina uppfattningar och prioriteringar måste det emellertid utvecklas och definieras tydligare; begreppet informationskompetens uppfattas som på sätt och vis ofärdigt. Tydligare konturer och fastare struktur får det $\mathrm{i}$ och för sig när det relateras direkt till en viss pedagogik och i texten ses PBL som dess förutsättning. Därigenom uppmärksammas också behovet av ett nära samarbete med lärarkåren och en förståelse för att de förändringar som fordras vad gäller pedagogik och undervisningsformer måste ske i dialog med dessa.

\section{Diskursiva betydelsestrukturer}

\section{Diskursanalytiska termer och begrepp}

I det följande kommer de iakttagelser som gjordes i närläsningen av texterna att utnyttjas för att försöka analysera de betydelser och innebörder som konstitueras genom användningen av begreppet informationskompetens i den aktuella diskursen. Till att börja med bör emellertid de diskursanalytiska begrepp och modeller som utnyttjas i analysen introduceras 
och förklaras så långt det är möjligt. I det här sammanhanget har metodologiska resonemang från i första hand Winther Jørgensen \& Phillips (2000) och Fairclough (1995) varit av avgörande betydelse för undersökningen.

Vid sidan av begreppet diskurs kommer ytterligare en övergripande term att användas, nämligen diskursiv händelse, vilken betecknar ett konkret tillfälle av språkanvändning. Man kanske kan formulera det så att en diskursiv händelse utgörs av texten och de omständigheter som förknippas med den - dess omgivande kontext.

För att kunna studera själva begreppet, informationskompetens, och de konsekvenser det har, måste det sättas i relation till ett antal andra viktiga begrepp i den aktuella diskursen. Vad det i praktiken är fråga om är att kontextualisera informationskompetens och andra för diskursen betydelsefulla begrepp i enlighet med Ekegrens resonemang. Detta underlättas genom att utnyttja ett antal diskursanalytiska termer vars funktion är just den att åskådliggöra tecknens inbördes förhållanden.

Med nodalpunkt förstås ett inom diskursen privilegierat tecken från vilket andra tecken får sin betydelse. Övriga tecken inom en diskurs etableras alltså genom att sättas i relation till dessa nodalpunkter. Inom den aktuella diskursen skulle viktiga begrepp som t.ex. bibliotek, utbildning, lärande och naturligtvis informationskompetens kunna utgöra sådana nodalpunkter.

Samtliga tecken inom en diskurs - vilka alltså får sin betydelse utifrån de relationer, förhållanden, de står i till diskursens övriga tecken - kallas moment. Winther Jørgensen \& Phillips (2000) använder sig av ett fisknät som liknelse för att beskriva strukturen: varje tecken motsvaras av en knut i nätet. Utifrån denna syn på diskursen kommer den att uppfattas som ett system av fixerade betydelser.

Genom att föra in begreppet element ges emellertid en möjlighet att uppmärksamma den risk för förändring som en diskurs hela tiden är utsatt för; den variation som är en konsekvens av tecknens, ordens, mångtydighet: ett element är nämligen ett tecken vars mening inte är slutgiltigt fixerad. Den aktuella eller temporära mening ett element ges får det genom att sättas i relation till andra element i en faktisk artikulation. Diskursen försöker fixera betydelsen genom att reducera elementens mångtydighet, att göra dem till moment, men - och detta är viktigt - denna fixering är aldrig total. Övergången från element till moment kan aldrig helt slutföras. Observera att en nodalpunkt också kan vara ett element.

För att kunna diskutera elementens rörlighet inom diskursen finns det anledning att introducera termen ytande signifikant. En ytande signifikant är ett element (möjligen också en nodalpunkt) som i särskilt stor utsträckning är ofixerad, öppen för olika betydelser. Därigenom kan den variation eller ambivalens som kan omge ett begrepp, också i en och samma diskurs, beskrivas.

\section{Sammanhangen - de diskursiva händelserna}

De diskursiva händelser i vilka de två texterna Studenternas bibliotek och Biblioteksbarometer 2000 ingår har det gemensamt att de i förhållande till diskursen är extroverta, de inbegriper en målgrupp utanför biblioteksvärlden (om också inte enbart). Den diskursiva händelse som BIBSAM-rapporten är en del av är en statlig myndighets presentation av en officiell utredning. Som sådan får den en i viss mån uppfordrande eller bemyndigande prägel. Lunds universitets biblioteksbarometer är inte av nationellt intresse på samma sätt som BIBSAM-rapporten men den diskursiva händelse den ingår $\mathrm{i}$ innefattar ett stort universitets utvecklings- och kvalitetsarbete. Det innebär att också den ställer vissa anspråk vad gäller auktoritet och trovärdighet.

De diskursiva händelser som innefattar Agneta Lantz föredrag och Boel K. Gustafssons magisteruppsats är däremot mer introverta vad gäller målgrupp. Lantz föredrag är i första hand ämnat för en publik bestående av bibliotekarier eller andra biblioteksföreträdare. Det innebär att man kan förvänta sig en 
högre grad av konsensus, eller åtminstone att förståelsen av olika resonemang är större hos publiken än den annars skulle vara. Eftersom det handlar om ett föredrag vid en konferens vars uttalade mål är att diskutera informationskompetens finns det också ett utrymme för större engagemang eller rent av entusiasm än i de andra diskursiva händelserna. Också i Gustafssons fall kan man förvänta sig att en högre grad av förståelse för ett biblioteksrelaterat perspektiv förutsätts hos den tilltänkta målgruppen. Det faktum att den diskursiva händelsen inbegriper presentationen av en akademisk uppsats medför särskilda konsekvenser. De resonemang och påståenden som formuleras förväntas vara väl underbyggda och tydliga och där det i Lantz föredrag kan finnas utrymme för viss vidlyftighet och svepande argumentation förväntas Gustafssons uppsats snarare präglas av återhållsamhet och moderation.

\section{Informationskompetens som ytande signifikant}

Som framgått av läsningen av texterna ovan finns det all anledning att betrakta informationskompetens som ett element snarare än som ett moment. Begreppet kan inte sägas ha fixerats i så måtto att det givits en entydig och bestämd innebörd. Betraktat som ytande signifikant kan man undersöka vilka andra begrepp det relateras till för att ges en mening eller betydelse.

Informationskompetens relaterat till bibliotek: Till att börja med måste man konstatera att bibliotek som betydelsefullt begrepp är närvarande genom hela diskursen, det gäller också för de artikulationer som är av intresse för undersökningen. Ändå är det inte i någon högre grad som begreppet informationskompetens får sin betydelse eller mening utifrån att det relateras till bibliotek. Möjligen kan man säga att det får en indirekt betydelse, som någonting vars befrämjande biblioteken är väl ämnade att ta ansvar för.

Så är t.ex. fallet i Gustafssons uppsats - begreppet ges inte någon betydelse som är direkt relaterad till bibliotek - men däremot menar hon att en utveckling av begreppet måste ske inom biblioteksvärlden.
BIBSAM-rapportens närmast biblioteksnedvärderande formulering kring informationskompetens och biblioteksanvändning skulle kunna uppfattas som en artikulation som knyter innebörden hos begreppet till bibliotek och biblioteksverksamhet, men utifrån det tidigare resonemanget måste man konstatera att förhållandet snarare är det motsatta. Innebörden kommer att fokuseras kring företeelser som inte är biblioteksrelaterade. Det främsta undantaget är den artikulation som egentligen är minst sysselsatt med att formulera någon närmare beskrivning av vad begreppet egentligen betyder, nämligen den vi finner i Biblioteksbarometer 2000. Där etableras informationskompetens vid sidan av kompetens $\mathrm{i}$ informationssökning som någonting som inbegriper att använda bibliotek.

Informationskompetens relaterat till utbildning: I BIBSAM-rapporten kan vi konstatera att begreppet framförallt kom att etableras utifrån dess relation till utbildning. Den innebörd begreppet fick där (förmågan att söka, kritiskt värdera och kreativt utnyttja information) skulle vara ett mål för högskolans utbildning. Detta är egentligen inte förvånande om vi re ekterar över hela den diskursiva händelsen. I ett sammanhang där det gäller att fånga uppmärksamheten hos beslutsfattande företrädare inom hela universitets- och högskolevärlden framstår utbildning som ett mycket grundläggande och privilegierat begrepp.

Faktum är emellertid att informationskompetens etableras som ett mål för universitets- och högskoleutbildningen i alla de texter som undersökts, det är bara artikulationen som varierar: i biblioteksbarometern som inte gör någon närmare bestämning av begreppet formuleras det som ett krav föreskrivet $\mathrm{i}$ lag; i Lantz föredrag kommer det att innebära förmåga att handla i en snabbt föränderlig och informationsrik miljö och i Gustafssons uppsats är informationskompetens som utbildningsmål själva grunden för frågeställningen.

Informationskompetens relaterat till lärande: I BIBSAM-rapporten artikuleras informationskompetens 
som en förutsättning för eller rent av en del av det livslånga lärandet. Det som fokuseras i sammanhanget är förmågan att tillvarata information och att effektivt tillgodogöra sig nya kunskaper. Resultatet blir också att informationskompetensen etableras som någonting av stor betydelse även utanför den aktuella diskursen. Även i Lantz föredrag relateras informationskompetens till livslångt lärande. Dels relateras till begreppet $\mathrm{i}$ anslutning till den Doyleinspirerade taxonomin av en informationskompetent person; dels knyts den vidareutveckling av resonemanget som räknar upp ett antal betydelsefulla egenskaper och karaktärsdrag, till livslångt lärande. Gustafssons uppsats artikulerar också en relation mellan informationskompetens och lärande. Här är det emellertid en mer begränsad, men samtidigt mer konkret relation som etableras: en förutsättning för framgångsrik undervisning i informationskompetens är en bred tillämpning av PBL-pedagogiken.
Informationskompetens relaterat till samhälle och utveckling: Framför allt i de båda introverta diskursiva händelser som undersöks i uppsatsen kommer informationskompetens att relateras till samhället och samhällsutvecklingen. I Lantz föredrag artikuleras informationskompetens som ett samhälleligt krav, själva nyckeln till dagens och morgondagens samhälle: en livsnödvändig förmåga $i$ informationsåldern och en förutsättning för att nå upp till samhälleliga krav på kvalitet och effektivitet. Gustafssons uppsats kom att artikulera viss tvekan inför mer vidlyftiga beskrivningar av informationskompetens, men trots viss ambivalens och utan någon tydligare innebörd etablerades begreppet som betydelsefullt för samhällsutvecklingen.

Betydelsestrukturer som artikulerar innebörden av informationskompetens: De betydelsestrukturer som uppmärksammats i diskursen så här långt kan sammanfattas i följande uppställning:

\begin{tabular}{|c|c|c|}
\hline Nodalpunkten & ger den ytande signifikanten & innebörd \\
\hline Bibliotek & Informationskompetens & $\begin{array}{l}\text { - Färdigheter i att söka litteratur och använda bib- } \\
\text { liotek. }\end{array}$ \\
\hline Utbildning & Informationskompetens & $\begin{array}{l}\text { - Förmåga att söka, kritiskt värdera och kreativt } \\
\text { utnyttja information. } \\
\text { - Föreskrivet i lag. } \\
\text { - Förmåga att handla i en snabbt föränderlig och } \\
\text { informationsrik miljö }\end{array}$ \\
\hline Livslångt lärande & Informationskompetens & $\begin{array}{l}\text { - Person som: uppmärksammar ett informati- } \\
\text { onsbehov; inser att information är grunden för } \\
\text { kloka beslut; identifierar lämpliga informations- } \\
\text { sökningshjälpmedel; utvecklar effektiva sökstra- } \\
\text { tegier; kritiskt granskar information; organiserar } \\
\text { information; integrerar ny information med be- } \\
\text { fintlig kunskap; använder information kritiskt. } \\
\text { - Ansvar för eget lärande; söker information för } \\
\text { problemlösning och beslutsfattande; ingår i in- } \\
\text { formella kontaktnätverk ; använder en arsenal av } \\
\text { effektiva strategier för att hålla jämna steg med } \\
\text { utvecklingen och har förmågan att kritiskt gran- } \\
\text { ska och värdera informationen. }\end{array}$ \\
\hline Lärande & Informationskompetens & Förutsätter PBL-pedagogik. \\
\hline Samhälle och utveckling & Informationskompetens & $\begin{array}{l}\text { - Ett samhälleligt krav; nyckeln till dagens och } \\
\text { morgondagens samhälle; en livsnödvändig för- } \\
\text { måga i informationsåldern och en förutsättning } \\
\text { för att nå upp till samhälleliga krav på kvalitet } \\
\text { och effektivitet } \\
\text { - Betydelsefullt (för samhället). }\end{array}$ \\
\hline
\end{tabular}




\section{Informationskompetens som nodalpunkt}

Utifrån perspektivet att informationskompetens kommit att få en framträdande roll inom den undersökta diskursen kan det också vara intressant att betrakta begreppet som en nodalpunkt vilken genom att sättas i relation till andra begrepp, element, kommer att ge dessa mening och betydelse. Det kan vara värt att återigen påpeka att en nodalpunkt inte behöver vara fixerad, ett moment, utan kan vara ett element, eller en ytande signifikant, vars betydelse är artikulationsberoende.

Bibliotek och bibliotekarier relaterat till informationskompetens: När bibliotekens betydelse i BIBSAM-rapporten artikuleras utifrån begreppsbestämningen av informationskompetens som ett uttalat mål för universitets- och högskoleutbildningen ges de en ökad pedagogisk potential. Biblioteken kommer att etableras som en försummad pedagogisk resurs. Det är utifrån den uppfattningen en förskjutning av bibliotekens betydelse från serviceinrättningar till utbildningsinstitutioner artikuleras. Biblioteksbarometern uppmärksammar i relation till informationskompetens biblioteken som en studiemiljö som erbjuder ett spektrum av olika informationsvägar. Det är i denna egenskap biblioteken utgör en bättre miljö för befrämjandet av informationskompetens än schemalagd undervisning.

I Lantz konferensföredrag etableras biblioteken och bibliotekarierna som några som - utifrån informationskompetensens betydelse - går en spännande, utomordentligt viktig och in ytelserik framtid till mötes. För att nå dit fordras emellertid stora mått av energi och framåtanda, något man måste uppfatta existerar hos yrkesgruppen, åtminstone potentiellt, utifrån den aktuella argumentationen. Utifrån perspektivet att informationskompetens som mål måste genomsyra allt biblioteksarbete kommer bibliotekariernas pedagogiska roll att artikuleras väldigt kraftfullt. I Gustafssons magisteruppsats kommer informationskompetens mycket konkret att bli en fråga för bibliotekens utveckling; deras integration i den övriga högskoleutbildningen är vad kraven på informationskompetens egentligen handlar om.

Nya lärprocesser relaterat till informationskompetens: I anslutning till det livslånga lärandet, för vilket informationskompetensen sades vara central, artikulerades i BIBSAM-rapporten ett framtidsrelaterat perspektiv där ett mer självstyrt och individualiserat lärande förutspås. För dessa nya förväntade lärprocesser sägs studenternas förmåga att tillvarata information vara avgörande för kvaliteten.

I Lantz föredrag formuleras ett liknande, men mer anspråksfullt, resonemang; där artikuleras en relation där informationssökning och informationsutnyttjande med hjälp av ny informationsteknologi står i centrum för nya lärprocesser. Det är dessutom ett ansvar för bibliotekarierna att se över utbildningssystemets undervisningsprocesser.

Betydelsestrukturer där informationskompetens artikulerar innebörder: De betydelsestrukturer där andra element i diskursen ges innebörd av informationskompetens kan sammanfattas i följande uppställning:

\begin{tabular}{|l|l|l|}
\hline Nodalpunkten & ger elementen & Innebörd \\
\hline Informationskompe- & Bibliotek och bib- & - Försummad pedagogisk potential. \\
tens & liotekarier & - Potentiella utbildningsinstitutioner. \\
& & - Studiemiljö som erbjuder ett spektrum av olika informationsvägar. \\
& & Viktig och in ytelserik framtid. \\
& & - Inneboende energi och framåtanda. \\
& & - Vörväntad integration i den övriga högskoleutbildningen. \\
& & - \\
\hline $\begin{array}{l}\text { Informationskompe- } \\
\text { tens }\end{array}$ & Nya lärprocesser & - förmåga att tillvarata information är avgörande. \\
& & - I centrum står informationssökning och informationsutnyttjande \\
\end{tabular}




\section{Slutdiskussion - begreppet Informationskompe- konsekvenser för diskursen}

\section{Vilka betydelser ges begreppet informationskompe- tens}

Begreppet ges olika betydelser i högskolebiblioteksdiskursen. Ur ett mer övergripande perspektiv, som ett slags grundföreställning, konstitueras informationskompetens i diskursen som någonting som bibliotekarier och bibliotek är särskilt lämpade att ansvara för; rent av någonting som förutsätter bibliotek och bibliotekarier. Därigenom är det lätt att uppfatta användningen av begreppet som en - medveten eller omedveten - strategi för att marknadsföra biblioteken. Frågan är emellertid i vilken utsträckning denna grundföreställning får stöd i de mer explicit uttalade betydelser diskursen ger begreppet informationskompetens.

Intressant är att konstatera att de två diskursiva händelser jag relaterat till som extroverta, vilka har en viktig målgrupp utanför biblioteken, skiljer sig åt markant när det gäller att ge begreppet en innebörd. I BIBSAM-rapporten fick begreppet en tämligen vid innebörd som snarare relaterade till företeelser kopplade till ämnesanknuten undervisning än sådant som direkt skulle kunna relateras till biblioteksverksamhet. I Biblioteksbarometern däremot knöts begreppets innebörd - i den mån det överhuvudtaget gavs någon - mycket konkret till biblioteksverksamhet.

Om informationskompetens diskuteras utifrån de vida beskrivningar som framförallt kommer att knyta begreppet till kunskapsinhämtning och lärande mer generellt, kan man fråga sig i vilken utsträckning det kommer att motivera en ökad prioritering av biblioteken. Tidigare konstaterades att det för att skapa gehör hos universitets- och högskoleföreträdare utanför biblioteken, fanns anledning att tona ned de mer biblioteksrelaterade aspekterna av begreppet. Begreppet kommer att konstitueras som någonting som huvudsakligen har att göra med undervisning och lärande. Frågan är bara vilka anspråk biblioteksföreträdare sedan kan formulera utifrån begreppet om det framförallt kommer att uppfattas som en angelägenhet för ämneslärare och -undervisning.

Undviker man att ge begreppet en mer uttalad beskrivning och nöjer sig med att å ena sidan knyta det relativt hårt till bibliotek och biblioteksverksamhet och å andra sidan relatera till det som någonting som är föreskrivet i lag, finns risken att man inte tas på allvar. Åtminstone om det som föreskrivs i lagen återigen refererar till sådant som de esta lärare och ämnesföreträdare menar sig själva kunna bibringa studenterna. Så tror jag nämligen att den avsedda gruppen skulle uppfatta den aktuella lagtexten om de läste den. Jag tror, i linje med hur Boel K. Gustafsson formulerade det $\mathrm{i}$ sin magisteruppsats, att man i bibliotekssammanhang måste vara mycket uppmärksam på vilken betydelse begreppet kommer att få. Ett tomt begrepp kommer inte att tjäna något syfte utan bara reducera auktoriteten hos den som utnyttjar det.

Inte minst $\mathrm{i}$ det som tidigare refererats till som introverta diskursiva händelser konstitueras informationskompetens som ett begrepp av stor samhällelig och framtidsinriktad betydelse. För att kunna anpassa sig till framtidens krav och äga förutsättningar för livslångt lärande måste individen besitta en mängd förmågor och karaktärsdrag och dessutom agera i enlighet med väldefinierade handlingsmönster. Informationskompetens konstitueras som en livsnödvändig förmåga.

Jämför man med diskussionen ovan kan man konstatera att begreppet i de här sammanhangen konstitueras utifrån tydliga, gärna biblioteksrelaterade, innebörder. Problemet är snarare att de är för konkreta eller väl avgränsade. När begreppet samtidigt som det ges väldigt omfattande och avgörande implikationer, begränsas mycket snävt vad gäller nödvändiga och tillräckliga egenskaper, blir konsekvenserna lätt problematiska. Många människor riskerar att på förhand exkluderas om informationskompetens, som det formuleras i diskursen, ses som det som krävs för att nå framgång i livet. Att etablera informationskompetens utifrån den här typen av generaliseringar 
riskerar att få motsatt effekt; man värjer sig för något som påstår sig vara ett slags universallösning.

\section{Attityder och föreställningar som omger begreppet}

En påtaglig uppfattning som diskuterades redan i början av förra avsnittet är att informationskompetens är någonting bibliotek och bibliotekarier är särskilt väl lämpade att ta ansvar för. Mer eller mindre outtalat genom hela diskursen löper, vill jag påstå, uppfattningen att bibliotek och bibliotekarier helt enkelt är en förutsättning för informationskompetenta studenter. Sätter man dessutom en sådan föreställning i relation till vad som sades ovan om informationskompetensens generella nödvändighet, blir slutsatsen att biblioteken blir en förutsättning för alla individer som vill uppnå något slags framgång $\mathrm{i}$ framtidens samhälle.

Även om lärarna ofta framhålls som en viktig grupp det gäller att samarbeta med för att åstadkomma en vitt utbredd informationskompetens, uppfattas initiativet och ansvaret ligga hos bibliotekarierna. Ser man till den stora betydelse man tillmäter informationskompetens är det lätt att uppfatta detta ansvar som någonting som $\mathrm{i}$ grunden verkligen borde förändra den framtida yrkesrollen: såväl status- som lönemässigt.

Förväntningar och förhoppningar som knyts till begreppet

Tydligast tror jag tror jag de förhoppningar som knyts till begreppet formuleras hos Boel K. Gustafsson när hon menar att det til syvende og sidst är en fråga om bibliotekens integration i den övriga högskoleutbildningen. Även om det inte alltid formuleras med samma pregnans, etableras det ofta som själva grundförutsättningen för diskussionen kring informationskompetens. Särskilt intressant anser jag förhoppningen om bibliotekens förändrade status från serviceinrättningar till utbildningsinstitutioner vara.

I den strängt formella värld som universitet och högskolor utgör, tror jag att en sådan förändring i synsätt kommer vara svårare att åstadkomma än man kanske föreställer sig. Utan att avsiktligt raljera kan man försöka föra resonemanget till sin spets: Om bibliotekarier ska få samma status som lärare måste de naturligtvis få samma anställningsformer dvs. anställas som universitetsadjunkter (eller lektorer), biblioteken bör få reella möjligheter att bedriva forskning och naturligtvis egna professurer: Frågan är om någon intresserar sig för en sådan utveckling i Sverige idag; i vilket fall som helst så tycks den mycket avlägsen.

Utifrån vilka anspråk etableras begreppet informationskompetens

Utifrån analysen ovan kan man konstatera att etablerandet av begreppet informationskompetens kommit att få långtgående konsekvenser för synen på högskolebibliotek och där verksamma bibliotekarier inom den egna, biblioteksrelaterade diskursen. Man uppfattar sig som en sorgligt outnyttjad pedagogisk resurs som måste tas i anspråk - och vars status måste lyftas från att vara serviceinrättning till att bli utbildningsinstitution. I diskursen kommer biblioteken att konstitueras som en förutsättning för nya pedagogiska riktningar inom högskoleutbildningen. Den kompetens som finns på biblioteken saknar motsvarighet inom någon annan del av utbildningssystemet och denna kompetens är fullkomligt central för de nya lärprocesser som kommer att prägla universitet och högskolor.

\section{Avslutande synpunkter}

Informationskompetens är ännu inte, vill jag påstå, tillräckligt väl etablerat för att kunna tjänstgöra som det centrala begrepp det ofta har kommit att framstå som. Förutom att den diskussion om begreppets innebörd som Gustafsson efterlyste måste nå längre, måste begreppet framförallt komma att omfattas av många er utanför biblioteksvärlden: det måste bli en del av en betydligt större diskurs.

Lyckas detta, på ett sådant sätt att begreppet kommer att konstituera en del av vad vi kan referera till som bibliotekens utveckling och den framtida bibliotekarierollen är det gott och väl - om inte likaså: Jag tror inte att den pedagogiska utvecklingen på biblioteken 
står och faller med genomslagskraften hos ett enskilt begrepp. Språket konstituerar möjligen verkligheten, men språket har oanade resurser och ord, liksom människor, är inte oersättliga.

\section{Kilder}

Gustafsson, B.K. (1998). Informationskompetens - ett nytt mål för den högre utbildningen?: Bibliotekarien befäster sin roll som pedagog? Uppsala : Uppsala Universitet, Institutionen för kultur- och biblioteksstudier. Magisterafhandling

Hagerlid, J. (1996). Studenternas bibliotek. Stockholm : BIBSAM. Lokaliseret den 1. juli 2003 på World Wide Web: http://www.kb.se/bibsam/utredn/ sbfulltxt.htm (Förenklad html-version)

Lantz, A. (1997). Informationskompetens - ett centralt utbildningsmål för den högre utbildningen, Linköping electronic articles in computer and information science, 2(10) Nr. 02. Lokaliseret den 1. juli 2003 på World Wide Web: http://www.ep.liu.se/ea/ cis/1997/010/02/index.html

Lindberg-Sand, §. (2001). Biblioteksbarometer 2000, Rapport / Lunds universitet, Utvärderingsenheten, Nr. 2001:210. Lokaliseret den 1. juli 2003 på World Wide Web: http://www.evaluat.lu.se/publ/ Bibl.baro/Biblioteksbarometer.pdf.

\section{Litteratur}

BIBSAM. Kungl. bibliotekets avdelning för nationell samordning och utveckling (2003). BIBSAM. Lokaliseret den 1. juli 2003 på World Wide Web: http://www.kb.se/BIBSAM/bibsam.htm

Doyle, C.S. (1994). Information literacy in an information society: A concept for the information age. Syracuse, NY. : ERIC Clearing House on Information and Technology

Ekegren, P. (1995). The reading of theoretical texts: A critique of criticism in the social sciences. Uppsala : Department of Sociology, Uppsala University.Dok torafhandling

Eld, C. (2001). Meningen med informationskompetens: En undersökning av begreppet informationskompetens $i$ en biblioteksdiskurs. Uppsala : Uppsala universitet, Institutionen för ABM, estetik och kulturstudier. Lokaliseret den 1. juli 2003 på World Wide Web: http://www.abm.uu.se/publikationer/ 2001/109.pdf Magisterafhandling

Fairclough, N. (1995). Critical discourse analysis. London : Longman Högskolelag, SFS nr: 1992: 1434

Winther Jørgensen, M., \& Phillips, L. (2000). Diskursanalys som teori och metod. Lund : Studentlitteratur.

Wood, L.A., \& Kroger, R.O. (2000). Doing discourse analysis. Thousand Oak : Sage. 